\title{
Architecture_MPS
}

\section{Identity and Conflict: Cultural Heritage, Reconstruction and National Identity in Kosovo}

Anne-Françoise Morel ${ }^{1}$

How to cite: Morel, A.-F. 'Identity and Conflict: Cultural Heritage, Reconstruction and National Identity in Kosovo.' Architecture_MPS, 2013, 3(1): 1, pp. 1-20. DOI: https://doi.org/10.14324/111.444.amps.2013v3i1.001.

Published: 01 May 2013

\section{Peer Review:}

This article has been peer reviewed through the journal's standard Editorial double blind peer review.

\section{Copyright:}

(C) 2013, The Author(s). This is an Open Access article distributed under the terms of the Creative Commons Attribution License (CC-BY) 2.0 https://creativecommons.org/licenses/by/2.0/, which permits re-use, distribution and reproduction in any medium, provided the original author and source are credited • DOI: https://doi.org/10.14324/111.444.amps.2013v3i1.001

\section{Open Access:}

Architecture_MPS is a peer-reviewed open access journal. 


\title{
Title: Identity and Conflict: Cultural Heritage, Reconstruction and National Identity in Kosovo
}

\author{
Author: Anne-Françoise Morel
}

Architecture_media_politics_society. vol.3, no.1.

May 2013

Affiliation: Universiteit Gent

\begin{abstract}
:
The year 1989 marked the six hundredth anniversary of the defeat of the Christian Prince of Serbia, Lazard I, at the hands of the Ottoman Empire in the "Valley of the Blackbirds," Kosovo. On June 28, 1989, the very day of the battle's anniversary, thousands of Serbs gathered on the presumed historic battle field bearing nationalistic symbols and honoring the Serbian martyrs buried in Orthodox churches across the territory. They were there to hear a speech delivered by Slobodan Milosevic in which the thenpresident of the Socialist Republic of Serbia revived Lazard's mythic battle and martyrdom. It was a symbolic act aimed at establishing a version of history that saw Kosovo as part of the Serbian nation. It marked the commencement of a violent process of subjugation that culminated in genocide. Fully integrated into the complex web of tragic violence that was to ensue was the targeting and destruction of the region's architectural and cultural heritage. As with the peoples of the region, this heritage crossed geopolitical "boundaries."
\end{abstract}

Through the fluctuations of history, Kosovo's heritage had already become subject to divergent temporal, geographical, physical and even symbolical forces. During the war it was to become a focal point of clashes between these forces and, as Anthony D. Smith argues with regard to cultural heritage more generally, it would be seen as "a legacy belonging to the past of 'the other," which, in times of conflict, opponents try "to damage or even deny." Today, the scars of this conflict, its damage and its denial are still evident. However, there are initiatives that are now seeking to use heritage - architectural and otherwise - as a way of fostering respect and dialogue between the cultures still reeling from the effects of the conflict. Having been seen as an originating factor in the conflict and made into a target for attack during the war, heritage is now seen as a facilitator for peacekeeping. As is to be expected, this is a complex, polemic, fraught and contested process. 


\title{
Title: Identity and Conflict: Cultural Heritage, Reconstruction and National Identity in Kosovo
}

\author{
Author: Anne-Françoise Morel
}

Architecture_media_politics_society. vol.3, no.1.

May 2013

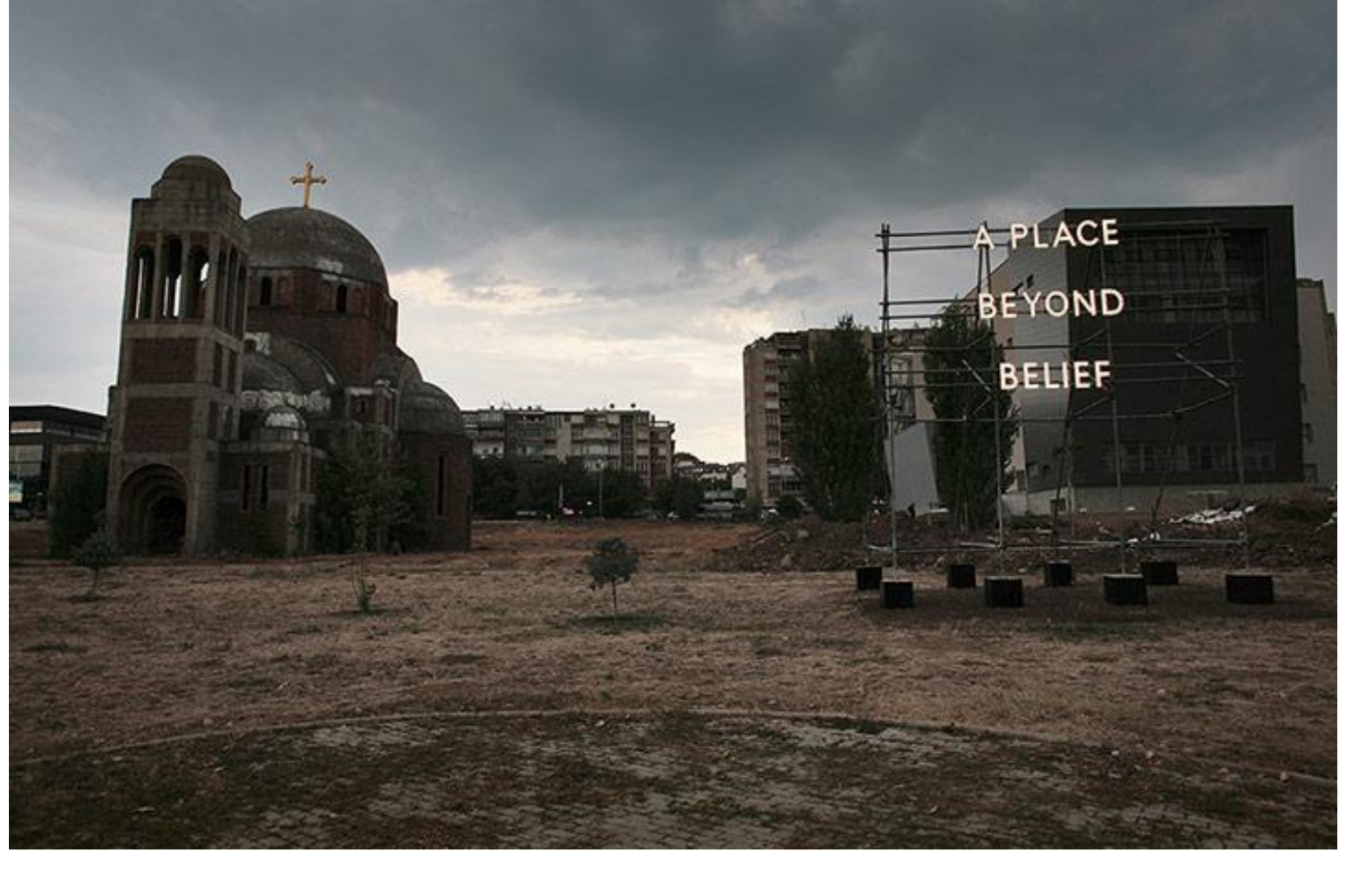

"A Place Beyond Belief". Installation by Nathan Coley. 2012.Photograph by Martin Godwin

The year 1989 marked the six hundredth anniversary of the defeat of the Christian Prince of Serbia, Lazard I, at the hands of the Ottoman Empire in the "Valley of the Blackbirds," Kosovo. On June 28, 1989, the very day of the battle's anniversary, thousands of Serbs gathered on the presumed historic battle field bearing nationalistic symbols and honoring the Serbian martyrs buried in Orthodox churches across the territory. They were there to hear a speech delivered by Slobodan Milosevic in which the thenpresident of the Socialist Republic of Serbia revived Lazard's mythic battle and martyrdom. It was a 


\section{Amps}

symbolic act aimed at establishing a version of history that saw Kosovo as part of the Serbian nation. It marked the commencement of a violent process of subjugation that culminated in genocide. Fully integrated into the complex web of tragic violence that was to ensue was the targeting and destruction of the region's architectural and cultural heritage. As with the peoples of the region, this heritage crossed geopolitical "boundaries."

Through the fluctuations of history, Kosovo's heritage had already become subject to divergent temporal, geographical, physical and even symbolical forces. ${ }^{1}$ During the war it was to become a focal point of clashes between these forces and, as Anthony D. Smith argues with regard to cultural heritage more generally, it would be seen as "a legacy belonging to the past of "the other," which, in times of conflict, opponents try "to damage or even deny." 2 Today, the scars of this conflict, its damage and its denial are still evident. However, there are initiatives that are now seeking to use heritage - architectural and otherwise - as a way of fostering respect and dialogue between the cultures still reeling from the effects of the conflict. Having been seen as an originating factor in the conflict and made into a target for attack during the war, heritage is now seen as a facilitator for peacekeeping. As is to be expected, this is a complex, polemic, fraught and contested process.

\section{The "Myth of Kosovo"}

"The rich plains of Kosovo, with their surrounding mountain ranges, belong to the most beautiful areas of Europe. Its central position in the Balkan Peninsula has determined the importance of the region, which covers an area about $10000 \mathrm{~km}^{2}$ and is situated at the intersection of major roads heading seaward.",3 Kosovo's central position has led both to its richness and its poverty. Over the centuries, it has shared and contributed to variegated cultures at the intersection of the Eastern and Western Roman empires, the Austro-Hungarian and Ottoman empires, and NATO and the Eastern Bloc. It has been the home of various peoples with diverse histories and backgrounds. This history saw the region blessed with a rich architectural heritage of churches, monasteries, mosques, hammams and kullas. The cultural diversity underlying this architectural heritage, however, has also been at the origin of ethnic clashes that have devastated the region.

The long-term historical tensions between Kosovo and Serbia have been crystallized in the "Myth of Kosovo." This myth recalls the "defeat" of Lazard I by the Ottoman Empire in $1389 .{ }^{4}$ According to this myth, the defeat of Lazard is seen as the "victory" of a martyr and has thus become a symbol of glorious Christianity: Lazard is presented as deliberately choosing defeat in the battlefield in order to gain the glory of God. ${ }^{5}$ The myth conceptualizes, as a single moment, the historical events that gradually saw the Serbs drawn under Ottoman dominance for several centuries. According to the myth, however, subjugation becomes a deliberate choice through which to celebrate the glory of God and, at the same time, elevates the Serbs to the status of a Godly "elected nation."

It is not a surprise that this myth was revived in the nationalistic discourses of Slobodan Milosevic in the late 1980s to give historic credibility to contemporary political claims of the Serbs. ${ }^{7}$ In reality, however, the myth had long since lost its real political significance with Serbian liberation from the Ottomans in 
1804. In fact, until the Yugoslav Constitution (and, in particular, the 1966 and 1974 constitutions) the Serb minority ruled and even repressed the Albanian majority of Kosovo. It was only once Marshall Tito granted Serbia's autonomous provinces equal voting privileges with republics at the federal level in 1966 that this more recent Serb-favored imbalance altered. ${ }^{8}$ Under these later constitutions, greater participation in provincial administration was granted to Kosovar Albanians. ${ }^{9}$ For some Serbs, this was seen as resulting in the old power balance reimposing itself - a concern heightened by the fact that new communist Albanian provincial representatives began calling for the elevation of Kosovo to republic status. After Tito's death in 1981, these nationalistic feelings led to Albanian demonstrations and riots, a local Serbian minority backlash and, ultimately, Slobodan Milosevic's curtailing of Kosovo's autonomy in 1989.

It was against this backdrop that Milosevic called upon the myth of Lazard as the symbol of Serb identity and emphasized the Serbian origins of Kosovo. Historically, Kosovo was not only a mythical part of the Serbian principality under Lazard - it also housed the Patriarch of the Serbian Orthodox Church in Pěc. Both myth and history, then, placed Kosovo at the centre of the Serbian nation. ${ }^{10}$ By recalling this, however, Milosevic not only restored the collective memory of the Serbs in Kosovo, but also stigmatized Kosovo as the cradle of all Serbian economic, social and political problems. ${ }^{11}$ During the next decade, nationalistic and ethnic claims by both parties would feed the growing contemporary political tensions on the ground and ultimately lead to the cruel war of 1998-1999. This conflict involved mass delocalization, genocide and the voluntary destruction of both Orthodox Christian and Islamist heritage as the opposing ethnic groups attempted to erase "the other."

\section{Buildings are politicized by why and how they are built, regarded and destroyed. ${ }^{12}$}

Although brought to the fore during the recent conflict, cultural heritage had been used to promote Serbian claims over Kosovo since 1912 - the very start of recent Serb dominance over the region. However, three specific justifications were set out for the rule of Serbs over Kosovo and its people in the political climate of 1989: "the moral right of a more civilized people"; "the ethnographic right of the people who 'originally' constituted Kosovo's majority population"; and "the Serb's historic right to the place that contained the Patriarchate buildings of the Serbian Orthodox Church." ${ }^{13}$ On these grounds, the Serbian Constitution was amended in 1990 to eradicate the remaining vestiges of Kosovo's autonomy through bans on the regional language, changes to the education curriculum and controls on the media and cultural activities. In this context, it is perhaps not surprising that during the 1999 war this eradication of Kosovan cultural identity would overflow into the targeting and destruction of Kosovar Albanian architectural heritage - the targeting and destruction of Kosovar Albanian architectural heritage, as this kind of destruction had already been part of established attempts to "de-Albanize" the region.

The destruction began in earnest in March 1998, when Serb forces initiated their military campaign against the Albanian population in Kosovo. Large numbers of Albanians were forcibly deported from their homes and their historic architecture was systematically targeted for destruction. The two most obvious reasons for this were, firstly, that the destruction of the built environment would diminish the possibility of return and, secondly, that it was a means to remove all visible evidence of Kosovo's 
deported Albanian community and its history. The primary targets of the Serb attacks were mosques. Approximately 207 of the 609 mosques in Kosovo sustained damaged or were entirely destroyed. ${ }^{14}$ Islamic religious schools, libraries, historic bazaars and kullas ${ }^{15}$ were also targeted, and seventy-five percent of the well-preserved Ottoman urban centers in Kosovar cities were severely damaged. In most cases the damage was not "collateral" but deliberate. ${ }^{16}$

A representative case was the razing to the ground of the Kulla of Jashar Pasha in Pĕc. This kulla dated back to 1809 and, as the Albanian League of Pĕc first met here in 1899, was an important Albanian landmark. ${ }^{17}$ The destruction took several days as the first attempts to set fire to the building failed, leading the arsonists to eventually climb ladders to set fire to the roof. ${ }^{18}$ Although, as this case exemplifies, the destruction of Albanaian homes and heritage was premeditated and sustained, Albanians did return in force after the war - in part stimulated by a feeling of international support. They too, however, engaged in similar violations of civil and human rights, as the Serbian minorities in Kosovo became the victims. During this period, and again during the "upheavals" of March 2004, ${ }^{19}$ the Serb Orthodox monasteries became the primary target of the Albanian mob. Orthodox religious architecture was - and remains - the symbolic centerpiece of Serb Orthodox presence in the region and, as such, became a natural retaliatory target.

In the civilian conflicts directly after the war, more than seventy buildings were vandalized or destroyed in revenge-attacks. In the events some years later, nineteen people were killed and thirty-five Serbian Orthodox churches and monasteries were destroyed on 17 March, $2004 .^{20}$ Tonka Kostadinova suggests that the specific rationale behind these later attacks on Serbian Orthodox heritage can be explained by two factors - again both historic and political. Firstly, the sites were generally perceived as "political statements," given that they had been built or were restored under Milosevic as part of attempts to secure full Serbian control over the region. Secondly, historical misinterpretations led to the false assumption that many Serb Orthodox monasteries were originally Albanian religious buildings before being forcibly taken over by the Serbian Church. ${ }^{21}$ Clearly, then, both the 1998-1999 war and the subsequent conflicts between inhabitants were fostered by recourse to culture and heritage.

Throughout this period Albanians and Serbs have handled competing versions of Kosovo's history, and culture and politics have become entangled in the nationalistic claims of both sides. As a result, and in parallel with the other Yugoslav wars, the Kosovo conflict has condensed the notion of collective memory and common history into a radical nationalistic and partial discourse. In this discourse, art and architecture have become proxies through which ideological, ethnic and nationalist conflicts have been fought out, and, inevitably, both have taken on totemic qualities. A mosque or a church is no longer a place of worship, but a token of the presence of a community marked for erasure. Similarly, the remains of a library or art gallery becomes something more than a standard cultural building - it becomes a container of historic memory - evidence that a community's history extends to the past and is legitimized in its present and future existence. Even after the war, culture and heritage remain important. 


\section{Puisque les guerres commencent dans l'esprit des hommes, c'est dans l'esprit des hommes que l'on doit construire les défenses de la paix. ${ }^{22}$}

One of the things that this continued importance of architectural heritage seems to suggest is that while in periods of conflict cultural heritage can be used to emphasis differences, in periods of reconciliation it may be able to play a different role - it may be able to symbolize the reality of co-existence and a common past. This position has been argued on many occasions at UNESCO, the Council of Europe, and the Institute for Cultural Diplomacy. ${ }^{23}$ In his inaugural speech at the UN Conference on Reinforcement and Cooperation in South-East Europe, for example, Kōichirō Matsuura, Director-General of UNESCO ${ }^{24}$, argued just that. Matsuura emphasised the role of culture and heritage in what he called sustainable peace, intercultural dialogue and economic development:

“...The multiple source, cross-cultural fertilization that comes from every culture, is the only way to thwart the ambitions of isolationism...Heritage and dialogue, as a people become aware of the many influences that have shaped its history, make it better able to build peaceful relations with others... Economic heritage and development, as a new approach to the management of cultural heritage, can promote economic development and generate new forms of creativity..." 25

In a paper on the perception of "the other," Margarita Alexandra Coppi Agostinelli echoes the same arguments and equally emphasizes the role of culture in potentially establishing interest, respect and openness between different communities and nationalities. She suggests that many inter-ethnic conflicts are not only caused by economic or territorial issues, but also by false apprehensions based upon extreme religious and political ideologies that create a pejorative view of "the other." ${ }^{26}$ In order to counter this problem, culture, she argues, can be used as a platform for dialogue - upon the condition that it is depoliticised and appreciated for its artistic, historical and heritage values. ${ }^{27}$

In the context of Kosovo, these arguments are of course particularly pertinent. Outstanding architectural monuments going back to the Middle Ages and the Ottoman period attest to the historic continuity of life in Kosovo, and to the exceptional artistic crafts of its inhabitants. Indeed, Kosovo can be considered a reduced-scale model of the Balkans in this sense. Its heritage includes fourteenth-century churches and monasteries, mosques of great stylistic perfection and many exceptional non-religious buildings that all testify to the dense multicultural artistic activity of the region. It is this richness and diversity, however, that gives rise to its emotive potential and raises specific problems for those from the international community - such as members of UNESCO - when attempting to bring about stability and continuity in the region.

When the 2004 UNESCO mission report entitled, Cultural heritage in South-East Europe: Kosovo Protection and Conservation of a Multi-Ethnic Heritage in Danger, was drafted, the expectations of Kosovo Serbians and Albanians concerning heritage management differed quite heavily. ${ }^{28}$ Albanians tend to have a slightly ambivalent relationship with their monuments dating from the Ottoman period, for example - partly as a result of the influence of the communist regime and its insistence on a detachment from religion as a prerequisite for being a "good civilian." 29 In contrast, Serbians feel personally concerned with the fate of the Orthodox monasteries, and this sensation (based on nationalistic sentiment) 


\section{Amps}

is something both the Church and the State have played upon. ${ }^{30}$ Despite this asymmetry, however, groups like UNESCO see the possibility of using an awareness and interest in the preservation of culture and heritage to bind the citizens of both communities together - particularly if they can be convinced to recognize a common responsibility and duty towards future generations.

Central to this potential use of heritage is, of course, a reconsideration of "the other" as an equal human being. Indeed, the Special Envoy of the Secretary-General to Kosovo, Martti Ahtisaari, has placed special emphasis on this by highlighting identity, culture, heritage and religion in the Comprehensive Proposal for the Kosovo Status Settlement. ${ }^{31}$ This report included detailed measures to ensure not only the promotion and protection of the rights of communities and their members, including minorities, but also the preservation and protection of cultural and religious heritage. Both were presented as necessary components to the development of a multi-ethnic, democratic Kosovo. With regard to heritage, the report proposed setting protective zones around more than forty key religious and cultural sites, regardless of their ownership, and also applied specific restrictions to activities within these zones to guarantee their peaceful existence and functioning.

Amongst the developments to follow from the report was the launch of the Implementation and Monitoring Council on February 13, 2013. This body includes the Kosovar government, representatives of the Serbian Orthodox Church, the Organization for Security and Co-operation in Europe (OSCE) and the EU. It is charged with the effective monitoring of the implementation of Kosovo's legislation on the protection of religious and cultural heritage - particularly with regard to the Serbian community in Kosovo. According to the EU special representative in Kosovo, Samuel Zbogar, it represents "a testimony of the EU's commitment to the protection of the cultural heritage of all communities, as well as an important step forward on Kosovo's commitments to EU accession."32

\section{"The continuing fragility of civilized society and decency is echoed in the fragility of its monuments." 33}

Despite initiatives such as the Comprehensive Proposal for the Kosovo Status Settlement, the reconciliatory role that can be played by culture and heritage depends heavily on the desire for reconciliation amongst the populace. As Robert Bevan has shown, restoring or reconstructing heritage can fuel the feelings of hatred it is intended to extinguish - and in some cases violence between the returnees and their former prosecutors is triggered or worsened. ${ }^{34}$ Rebuilding can be as symbolic as destruction, and construction can be used to "cement" the injuries of the past conflict. At times, it can also be used to deliberately mask the past and erase all traces of previous violence and injustice. At best, such cases represent a well-meaning, but clearly partial and only partly accurate, attempt to create a coherent narrative and identity. At worst, however, they do not allow for healing and deepen a particular community's sense of injustice.

In addition, instead of weaving the fabric of a former life back together, reconstruction can sometimes be read as creating monuments to the events that caused the destruction of that life. In its reconstructed form, for example, the Mostar Bridge - once the symbol of symbioses between variegated ethnic and religious 
populations - is now associated with the war. It is a reminder of past horrors, rather than the symbol of present harmonious reality - although it also expresses a statement of hope for a less divided future.

In the report, Erroneous - An Analysis of Numerous and Continuous Faults in Cultural Heritage, EC Ma Ndryshe echoes this perspective somewhat and suggests that, in Kosovo, the failure of some heritage projects is seen as a sign of governmental failure at all levels. ${ }^{35}$ In contrast, EC Ma Ndryshe argues that the successes of these projects are often considered reflections of community participation. This is a position echoed by Cultural Heritage Without Boarders (CHwB) in their report, Cultural Heritage, Reconciliation, Reconstruction, Hopes for the Future. ${ }^{36}$ Here, success is seen as involving the will to exchange the nationalist and separatist discourse - in which culture and heritage are often broadcasted for a discourse of tolerance and unification. ${ }^{37}$ Similar issues are picked up by Robert Bevan and others, who have all published papers and reports identifying the pitfalls of reconstruction and the importance of community engagement. ${ }^{38}$

Running through all these arguments is the idea that, firstly, affinity with local community, customs and culture is necessary if heritage is to function as an instrument for mutual respect and empathy. Secondly, that the effectiveness of cultural diplomacy depends on a willingness for dialogue and understanding between all parties, and thirdly, that using the reconstruction of heritage as a cultural facilitator of reconciliation requires a huge financial investment. Finally, all these arguments also caution against seeing heritage as a panacea for conflict resolution and indicate that post-conflict regions tend to rely heavily on the international community to establish heritage and reconstruction programs - something seen as inevitable given the lack of financial resources typical of a post-conflict region.

Embedded in these arguments is a recognition of the role, financial and otherwise, of external bodies and, as a corollary of that, an understanding of the need for projects to genuinely reflect the cultural conditions "on the ground," and not the values of those external bodies funding the reconstruction. As explicitly identified in the CHwB report, Cultural Heritage, Reconciliation, Reconstruction, Hopes for the Future, care must be taken that all sectors of society are engaged with the proposed heritage projects and that these projects are not only based upon the interests of the "international community" 39 - an issue of particular relevance in Kosovo where attempts to use heritage constructively have been driven by international bodies.

Europe, for example, has been very proactive in promoting the multicultural diversity of Kosovo. Indeed, the acceptance of multi-ethnicity and multiculturalism have been put forward as a conditio sine qua non for Kosovo's possible future accession to the European Union - as well as being recommended to aid in the achievement of sustainable peace and stability. ${ }^{40}$ In this scenario, it is duty of the Kosovar government to protect the rights of the minorities, even though the understanding of what that means may be based more on European Union notions and stereotypes than on the present values, history and traditions of Kosovo itself.

The reality today is that ninety percent of the Kosovo's population is Albanian. Therefore, the question of whether notions of multi-ethnicity and multiculturalism are little more than European projections based on the nostalgic idea of a Balkans' "golden age" is a pertinent one. It is arguable that if a false sense of 
diverse and varied cultural identity is imposed on Kosovo, the chances of using heritage to promote peace may be undermined. This is underlined by the recent decision of the Kosovo government to halt funding and participation in the restoration of Serb Orthodox churches left incomplete by the EU-organized Reconstruction Implementation Commission. ${ }^{41}$

Another point that has to be considered when questioning the use of architectural heritage to promote peace is that however laudable some reconstruction projects may be, many of the reconstructed Serb Orthodox churches and monasteries remain surrounded by military protection zones. The fear of Albanian attacks similar to those of $2004^{42}$ is clearly evident and is an obvious indication that "reconciliation" is far from being achieved. These protection zones were established by the Comprehensive Proposal for the Kosovo Status Settlement in order to:

"provide for the peaceful existence and functioning of the sites to be protected; preserve their historical, cultural and natural environment, including the monastic way of life of the clergy; and prevent adverse development around them, while ensuring the best possible conditions for the harmonious and sustainable development of the communities inhabiting the areas surrounding such sites." ${ }^{43}$

However lawful and necessary the decision to cordon these sites into protective zones was, the reality is that the Special Protective Zones prohibit free access to the sites and make daily life increasingly difficult for the surrounding community. The presence of police and military forces underline "the otherness" of the sites and do not promote dialogue and contact between the communities.

All of these potential failings and pitfalls in the use of architectural heritage as a reconciliatory device are inevitably more likely to emerge if projects are carried out in an isolated manner, without being part of a broader plan to integrate heritage into the communities of all parties. ${ }^{44}$ The case of Kosovo has shown this very clearly through a number of projects funded in isolation by investors from Saudi Arabia, namely the Saudi Joint Committee for the Relief of Kosovo and Chechnya (SJRC). The "reconstructions" funded by this group impose a new architectural typology that reflects Wahhabi Islam rather than the traditions of Balkan Islamic architecture. In the projects that the SJRC funds, the richly decorated Balkan interiors give way to the austerity demanded by Wahhabi Islam. ${ }^{45}$

On example is the Qater Lula mosque in the centre of Pristina. Four centuries old, it was not damaged during the war but was in disuse and disrepair. Rather than attempt the complicated task of restoration, the SJRC - the largest and most prominent Arab aid organization in Kosovo - had the old structure razed to the ground in 2000. In its place appeared a large white mosque wrapped with reflective windows. In the same year, another centuries-old mosque in the town of Rahovec, also undamaged during the war, was demolished and replaced with a new one. Even in projects where the original structure was retained, reconstruction often made it almost unrecognizable as a historic object. For instance, the Hamam mosque in Peja was plastered over and the portico was enclosed in a glass and metal frame to make it more austere.

In the case of at least one of these controversial projects, the impunity of the Saudi-backed construction crews was, however, challenged. The Hadum Mosque in Gjakova, a handsome stone structure with a large dome, was part of a historic complex in the centre of the old town that Serbian militias had badly damaged during the conflict. Although its stated intention was to "restore" the complex, the SJRC had the 
remains of the abutting sixteenth-century library bulldozed to make room for a new Islamic centre. After the Department of Culture (DOC) of the United Nations Mission in Kosovo (UNMIK) was notified, work on the project was stopped and the Saudis were ordered to "undo" the damage they had done, using historically appropriate materials and techniques. In response, the SJRC pulled its funding and left behind a demolished mosque and an empty lot. ${ }^{46}$

Some experts on Balkan architectural heritage have charged that alterations made to the mosques of Kosovo by the SJRC not only reflect the "architectural tastes" of the foreign financiers, but also reflect the imposition of their view of Islam itself. For some, such as Robert Bevan, these new buildings not only change the architectural forms of the region: they offer a toehold for what can be seen as "Islamic extremism" - a potentially dangerous influence in a fragile society in which religious differences have already played an important role in recent wars and terror. ${ }^{47}$

Focusing on architectural questions, however, Kosovo's head Imam, Sabri Bajgora, has also expressed dissatisfaction with the way some of the reconstruction projects have been carried out. Commenting on a range of projects, he states, "We are concerned that these were done improperly," and he underlines concerns about external influence: "They [the buildings] are our cultural heritage." ${ }^{48}$ However, the Saudi funders are not the only ones to blame in this regard. Andras Riedlmayer, one of the most outspoken critics of foreign-sponsored reconstruction projects in the Balkans, points out a lack of appreciation for, and identification with, Kosovo's Ottoman mosques more generally - even among the local staff of the agencies charged with their protection. For him, this lack of local concern reflects "the open hostility towards religion that was an absolute prerequisite for anyone who wanted to be seen as educated and 'modern' in communist Yugoslavia."49

Despite the problems and tensions such projects and comments reveal, there is clearly a strong belief and a growing body of evidence - that the conservation and development of cultural and historic environments can help in Kosovo - in promoting the process of reconciliation, strengthening self-belief, contributing towards growth, and thus helping fight poverty. One project that reflects this is the restoration of the several important kullas in the Peja region. This is an initiative organized by a group of collaborators including: the Council of Europe; $\mathrm{CHwB}$; the Kosovan Ministry of Youth, Culture and Sports; the municipality; local businesses and organizations; and the School of Architecture from Pristina. The aim of the project is, through restoration, to highlight the region's multicultural history and to contribute to reconciliation and economic regeneration. ${ }^{50}$

As part of this initiative, the region's cultural, religious and natural sites are being promoted as tourist destinations. To date, there has been massive local involvement and, according to $\mathrm{CHwB}$, it has already led to dialogue, and even social cohesion. ${ }^{51} \mathrm{CHwB}$ sees this local involvement as an example of a heritage initiative that is integrated into regional development and that supports the development of networks and cooperation between ethnic and religious groups. CHWB considers this kind of involvement to be a possible generator of income, and thus economic development. ${ }^{52}$

The restoration project of the clock tower in Rahovec is another success story based on the involvement of local people, the development of local networks and the fostering of inter-ethnic cooperation. Several people from different backgrounds worked together on this restoration project. According to $\mathrm{CHwB}$, this 
is another example of how local involvement can encourage mutual respect, understanding and trust between communities. The restoration of this historical monument also empowered local entrepreneurs to reinvest in and rediscover traditional craft and material techniques. ${ }^{53}$ This is a well-monitored heritage program that is not only stimulating dialogue, but is also increasing the economic capacities of local people.

In many ways, this program reflects arguments put forward in Lessons from Kosovo - How Post-Conflict Society is Dealing with Planning and Cultural Heritage - a workshop event that emphasized the economic advantages of heritage projects. It came out of Habitat Programs in Kosovo - a project led by $\mathrm{CHwB}$ and the UN that promoted the use of well-designed spatial and urban planning strategies as guides for local development. The restoration program in Rahovec aims to protect the environment and cultural heritage, and thus focuses on a reduction in the risk of natural disasters, the mitigation of the consequences of man-made problems and the creation of "spatial order"." It is equally aimed at using cultural heritage to create opportunities for education, fostering local development projects through the promotion of cultural tourism and strengthening the roles for women in Kosovar society. ${ }^{54}$

Both $\mathrm{CHwB}$ and the UN are engaged in training local government administrators in strategic planning and engaging the civilian population in participatory planning through the organization of workshops. This is an approach that has resulted in a greater sense of local ownership and better projects, and has even reduced costs associated with the planning process. In addition, the integration of cultural heritage projects into overall spatial and economic planning has helped promote projects such as a recently-opened bed and breakfast in a restored kulla in Junik. In cases like this, we see cultural heritage successfully integrated into municipal plans, creating conditions for development and economic growth - an issue of primary import in Kosovo, which continues to face acute challenges to its post-conflict reconstruction. ${ }^{55}$

Another example of inter-ethnic cultural exchange and economic growth through heritage management is Intersos, an Italian NGO with considerable humanitarian experience in Kosovo. ${ }^{56}$ Intersos decided to combine its heritage restoration and management programs with its programs aimed at fomenting and supporting civil society. Intersos has organized heritage tours that bring together practitioners, stakeholders and common citizens of both Serbian and Albanian origin. Although the first tours did not involve mixed groups or visits to the heritage sites of "the others," as enthusiasm for the tours spread, requests grew for mixed visits to all sites. ${ }^{57}$ These heritage tours are now followed by dialogue sessions that use cultural heritage as a starting point for discussions between different groups in which emphasis is placed on accepting identities and building community. These tours are part of wider efforts to reduce the political and religious "burden" carried by sites of heritage and they seek to widen the discussion around heritage to issues beyond isolated notions of identity.

By means of intercultural dialogue, then, Intersos has tried to promote a return to normal living conditions, the re-establishment of dialogue, the strengthening of peace, physical reconstruction and, in addition, economic growth. Their work has brought four key ideas to the fore: the importance of tolerance, the need to seek peace, the use of heritage as a "cure," and the transformation of ways of thinking and behaving. The reinterpretation of the sites, monuments and other cultural artifacts of the region that Insertos seeks to foster involves transforming the negative associations carried by sites of war 
into positive readings of reconciliation and respect. The intention is to use heritage and culture to remind people of different communities that they interacted and lived together peaceably in the past and can do so again. The aim is to transform the binary aggressor-victim relationship into one of mutual understanding. ${ }^{58}$

\section{Conclusion}

Despite the efforts, hopes and aspirations of those groups working toward peace in Kosovo through cultural understanding and dialogue, the political situation in the region is still complex. Kosovo remains in an extremely weak economic state and its political status has yet to be determined or accepted. It is ruled by a Kosovar Albanian majority, but a Serb minority still favours governance from Belgrade. Even the European Union seems unable to speak with one voice regarding the recognition of the region whether it should be defined as an independent nation or some other political entity remains an open question. $^{59}$

In this still unresolved context, the tension on the ground remains high. Nevertheless, both the Serbs and Kosovars are trying to adopt the political identity and attitude presented by the EU as a prerequisite for its cooperation - an identity based on European values of multicultural acceptance. If this political attitude proves to be little more than political expediency, as both parties seek a "fast-lane" to European integration, it is not certain to last - nor is it certain to provide sustainable peace or to be the basis of cross-cultural collaboration. Multiculturalism is indeed a fundamental element of Western Balkans history. However, it cannot be imposed on the contemporary landscape by "Brussels."

On the contrary, in order for an "attitude" of multicultural acceptance to be fully integrated into the mindset of the population, it has to be willingly accepted by all parties. At the moment, it is not. Serbian Orthodox religious sites remain under strong protection and thus secluded from society, not all war loot has been restored, and the Kosovar economy remains desperately weak. In these conditions, there are also fears that more ardent strands of religious beliefs are gaining influence in the region as it searches for its new identity. As a result, mistrust and potential conflict continue to hover over the region despite outward signs of - and external pressures for - multiculturalism.

In this context, it may well be arguable that the most important advances for the region are to be found in the political and economic spheres, but, as many of the projects described here begin to indicate, these advances can be underpinned by strengthening cultural ties. As a result, there is a potential role for architectural and cultural heritage in both the cementing of peace building and in economic development. This is a position that is ever more accepted today, with modern politics and diplomacy increasingly considering culture and heritage as "instruments for peace and reconciliation." This position is based upon the underlying assumption that nations cannot simply be understood as ideological or political concepts, but should be considered as cultural phenomena as well. ${ }^{60}$

Framed in this way, a collective cultural identity has come to be seen as fundamental to our understanding of nationhood. It offers a sense of continuity with the past, presents cultural unity to the population and provides communities with notions of collective destiny. Heritage protection, conservation and restoration 
are thus seen as playing a key-role in any society - but particularly in one attempting to overcome the sense of displacement caused by conflict. ${ }^{61}$ However, as the case of Kosovo shows clearly, if architectural heritage can be viewed as a powerful instrument in the building of nations, it can also be viewed as a tool and a target in their destruction. This is still a fine line that has to be trodden in the Kosovo of today. 


\footnotetext{
${ }^{1}$ Council of Europe, Steering Committee for Cultural Heritage, Heritage from Elsewhere, Heritage of Others, Outline of an Awareness-Raising Project (Brussels: CoE, 2004,), 2.Gabi Dolff Bonekämper, "Sites of Historical Significance and Sites of Discord: Historic Monuments as a Tool Discussing Conflict in Europe," in Forward Planning: the Function of Cultural Heritage in a Changing Europe, ed. Council of Europe (Brussels: CoE, 2000), 56.

${ }^{2}$ Anthony, D. Smith, National Identity (London: Penguin Books, 1991), 30. See also: Bertelmann Stiftung, The Cultural Dimensions of Conflicts from 1945 to 2007, Introduction and Summary (Guetersloh: Bertelmann Stiftung, 2009), 2.

${ }^{3}$ Koïchiro Matsuura, Cultural Heritage in South-East Europe: Kosovo. Protection and Conservation of a Multi-ethnic Heritage in Danger. Mission Report (Paris: UNESCO, 2004), 4.

${ }^{4}$ If the myth represents this battle as decisive, history is less radical. Neither the Ottoman Empire nor the Serbs could claim victory in the battle, as both parties suffered many important defeats during the confrontation. The Serbian forces lost the majority of their cavalry and many members of their aristocracy while the forces of the Ottoman Empire lost their Sultan Murat I and his legal heir. This bloody draw was only attributed as a victory for the Ottoman Empire in the following century.

${ }^{5}$ Inspired by a divine vision, Lazaro is said to have preferred the "eternal life" of martyrdom to a temporary victory upon earth. See: S. Puhala, L'autochtoniété des Albanais en Kosovo et le prétendu exode des Serbes à la fin du XVII siècle (Tirana: Editions 8 netori, 1985).

${ }^{6}$ This combination of a martyrology and historical fact was, for obvious reasons, used in the war propaganda of the 1990s. For more information, see: Jean-François Gossiaux, "Les Deux Passés du Kosovo," Socio-Antropologie 4 (1998): 3, accessed September 05, 2012. http:// socio-
} 
antropologie.revues.org/index130.html. For more information on the history of Kosovo, see also: Archimandrite A. Jeftitch, Dossier Kosovo (Lausanne: L'Age d'Homme, 1991).

${ }^{7}$ Dejan Dimitrijevic, Mémoire et histoire dans la culture politique Serbe (Paris: IFRI, 1999), 3, 4.

${ }^{8}$ Marshal Josip Broz Tito (1892-1980) was a Yugoslav revolutionary and statesman who was president between 1953 and 1980 . Under Tito, the two constituent provinces of Serbia, Kosovo and Vojodina, received substantially increased autonomy including de facto veto power in the Serbian parliament. It was part of Tito's "ambition" to create a republic of states with equal rights for all its members.

${ }^{9}$ Prior to 1989 , there was legal parity between Kosovo and the other republics, deriving from the 1974 constitution. Kosovo was granted almost all the rights of a republic and, accordingly, was entitled to participate in the decisions of the Federation and was responsible for implementing, enforcing and amending the Yugoslav Constitution. This included the ratification of international agreements and the formulation of Yugoslav foreign policy. Kosovo was also directly represented in federal bodies such as the Federal Parliament, the Presidency Cabinet, the Federal Court and the Federal Constitutional Court. Being a constituent part of the Federation, Kosovo was granted the right to have its own constitution, parliament and judiciary - including a constitutional court and a supreme court. Kosovo could also establish its own banking policy - within the common currency issue policy. See: D. Dajena Kumbaro, The Kosovo Crisis in an International Law Perspective: Self-Determination, Territorial Integrity and the NATO Intervention, Final Report (Brussels: NATO, 2001), 37. See also: Dennis P. Hupchick and Harold E. Cox, The Palgrave Concise Historical Atlas of The Balkans (New York: Palgrave, 2001), 50.

${ }^{10}$ The Pĕc District is located in the west of Kosovo. Ninety percent of its population is Albanian, but it also houses ethnic groups of Serbs, Roma and others. Pĕc has, however, been linked to the Serbian Orthodox Church for seven centuries and has been the recognized Seat and official residence of the Patriarchs of the Serb Orthodox Church for two hundred years.

${ }^{11}$ Part of the "symbolic" argumentation around this process involved emphasising the "messianic promise of resurrection" embedded in the old myth. See: Dimitrijevic, Mémoire et Histoire (Paris: IFRI, 1999), 6. In this light, it is clear that myth and heritage can be said to have played a central role in the propaganda of the war from its very beginnings.

${ }^{12}$ Robert Bevan, The Destruction of Memory: Architecture at War (London: Reaktion, 2006). See also: International Crisis Group, "Religion in Kosovo," ICG Balkans Report 105 (2001), 14.

${ }^{13}$ Andrew Herscher and Andras. Riedlmayer, "Monument and Crime: The Destruction of Architecture in Kosovo," Grey Room 1 (2000): 110, accessed August 07, 2012, http://jstor.org/stable/ 1262553.

${ }^{14}$ Figures cited from: Herscher and Riedlmayer, "Monument and Crime," 112.

${ }^{15}$ Originally a type of Ottoman tower house introduced after the Ottoman conquest in the Middle Ages, kullas remained common and were used by both the Christian and Muslim communities in the years of declining Ottoman power in the seventeenth century. In the twentieth century, they were primarily associated with prominent Albanian families.

${ }^{16}$ Herscher and Riedlmayer, "Monument and Crime," 112.

${ }^{17}$ The League aimed to defend the rights of the Albanians and to give them autonomous status within the Ottoman Empire. After an armed conflict with the Ottoman forces in 1900, the League ended its operations. For more information on this in the general context of the History of Kosovo, see: Noel Malcolm, Kosovo: A Short History (New York: New York University Press, 1998). ${ }^{1}$

${ }^{18}$ Herscher and Riedlmayer, "Monument and Crime," 118.

19 On March 15, 2004, an eighteen-year-old Serb was shot in the village of Čaglavica in the central region of Kosovo. Local Serbs demonstrated and blocked traffic in protest, blaming the Kosovars. On March 16, three Albanian children were drowned in the Ibar River near the Serb community of Zubin Potok. The Kosovar community suspected the Serbs of revenge. Even though this claim was never proven, it spawned more violence and almost ignited a new conflict. See NATO, History: KFOR Deploys, accessed April 5, 2013, http://www.aco.nato.int/kfor/aboutus/history.aspx.

${ }^{20}$ Herscher and Riedlmayer, "Monument and Crime," 112.

${ }^{21}$ Tonka Kostadinova. "Cultural Diplomacy in War-Affected Societies: International and Local Policies in the Post-Conflict (re-) Construction of Religious Heritage in Former Yugoslavia," (paper presented at the Academy for Cultural Diplomacy, Berlin, June 10-17, 2011 ), 12.

${ }^{22}$ This phrase is inscribed on the building housing the UNESCO Headquarters, in Paris. It is defined as the underlying principle of UNESCO as a UN institution. It translates as: Since wars begin in the minds of men, it is in the minds of men that we must build the defences of peace.

${ }^{23}$ See: Proceedings from Symposium on Cultural Diplomacy. At Aspen Institute of Colorado, The Phillips Collection Washington DC,

John Brademas Centre for the study of Congress, accessed January 15, 2013,

http://www.culturaldiplomacy.org/academy/index.php?Conferences-2012; see also The Ankara Conference on Peacebuilding \& Conflict

Resolution, "Using Cultural Diplomacy as a Tool to Build Sustainable Peace" (Ankara, April 17th - 19th, 2012), accessed February 15, 2013

http://www.culturaldiplomacy.org/gphr/index.php?en_acop-2012

${ }^{24}$ United Nations Educational, Scientific and Cultural Organization

${ }^{25}$ Koïchiro Matsuura, Inauguration speech at "Conférence de haut niveau sur le renforcement de la coopération en Europe du Sud-Est",

UNESCO, April 4, 2002, (Paris: Unesco, 2002) p.3. Accessed 25 March 2013

http://erc.unesco.org/SEEConference/docs/32\%20Conf\%C3\%A9rence\%20\%20sur\%201'Europe\%20du\%20Sud-Est.pdf

${ }^{26}$ Coppi Agostelli and Margarita Alexandra, "Cultural Diplomacy and the Concept of the Other" (paper presented at the International Conference on Cultural Diplomacy and the UN, New York and Washington, February

2012), http://www.culturaldiplomacy.org/academy/content/pdf/participant-papers/2012-02-

unccd/Cultural_diplomacy_and_the_concept_of_the_Other-_Margarita_Alexandra_Coppi_Agostinelli.pdf.

${ }^{27}$ EC Ma Ndryshe. "Erroneous. An analysis of Numerous and Continuous Faults in Cultural Heritage." Series Analysis “What Went Wrong”?

Forum 2015 - KFOS operational project, (2012): accessed 25 March 2013, http://kfos.org/erroneous-numerous-and-continuous-faults-in-culturalheritage/

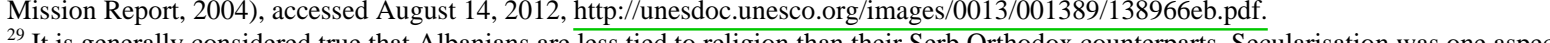
Mission Report, 2004), accessed August 14, 2012, http://unesdoc.unesco.org/images/0013/001389/138966eb.pdf.

${ }^{29}$ It is generally considered true that Albanians are less tied to religion than their Serb Orthodox counterparts. Secularisation was one aspect of the Communist period under Tito, whose influence was widely felt. In part as a result of this, Albanian Islam has taken on a relatively "secular" form in comparison to the more fundamental approach sometimes associated with the Serb Orthodox Church. As the Serbian Church is a national one that always supported the territorial claims of Serbia in Kosovo, it rapidly gained importance after the Communist period. See comments by Koïchiro Matsuura: Cultural Heritage in South-East Europe, 9. 


\footnotetext{
${ }^{30}$ This focus on its heritage has helped the Church gain renewed importance and has been particularly evident in the linking of heritage, Church and Serbian nationalistic claims. See: Siefer (ed). "Kosovo: Heritage or Sacrilege," in: Transitions Online: Regional Intelligence, accessed July 23, 2003., http://www.tol.org/client/article/10172-kosovo-heritage-or-sacrilege.html.

${ }^{31}$ Point 2.1 of the report reads: "Kosovo shall create appropriate conditions enabling communities, and their members to preserve, protect and develop their identities. The Government shall in particular support cultural initiatives from communities and their members, including through financial assistance." Point 2.2 states: "Kosovo shall promote a spirit of tolerance, dialogue and support reconciliation between Communities. It shall respect the standards set forth in the Council of Europe Framework Convention for the Protection of National Minorities and the European Charter for Regional or Minority Languages." Martti Athisaari, Comprehensive Proposal for the Kosovo Status Settlement (S/2007/168/Add.1), accessed August 18, 2012, http://www.unosek.org/docref/Comprehensive_proposal-english.pdf.

${ }^{32}$ Quoted in: Stojan Pelko, Implementation and Monitoring Council Established (Kosovo: European Union Office in Kosovo, 13 February 2013).

${ }^{33}$ Bevan, The Destruction of Memory, 9

${ }^{34}$ Bevan, The Destruction of Memory, 176-177.

${ }^{35}$ EC Ma Ndryshe, "Erroneous. An Analysis of Numerous and Continuous Faults in Cultural Heritage." Series Analysis “What Went Wrong”? Forum 2015 - KFOS operational project, (2012), accessed March 25, 2013, http://kfos.org/erroneous-numerous-and-continuous-faults-incultural-heritage/.
}

${ }^{36}$ Cultural Heritage Without Boarders, Cultural Heritage, Reconciliation, Reconstruction, Hopes for the Future (Stockholm: CHWB, 2005).

${ }^{37}$ Cultural Heritage Without Boarders, Cultural Heritage, Reconciliation, Reconstruction, Hopes for the Future (Stockholm: CHWB, 2005). See also: UNESCO, Cultural Heritage in South-East Europe: Kosovo (Paris: UNESCO, 2004).

${ }^{38}$ See: Bevan, The Destruction of Memory, 2006. Also see EC Ma Ndryshe, "Erroneous", 2012; and for further details see Cultural Heritage Without Boarders, Cultural Heritage, Reconciliation, 2005.

${ }^{39}$ Cultural Heritage Without Boarders, Cultural Heritage, Reconciliation, 2005. See also: Cultural Heritage Without Boarders, 2010 Projects (Stockholm: CHWB, 2010), accessed September 20, 2012, www.chwbkosovo.org.

${ }^{40}$ Stefan Lehne, "Kosovo and Serbia: Toward a Normal Relationship" Carnegie Policy Outlook (2013): 7. See also: International Civilian Office, Implementation of Special Protective Zones for Religious and Cultural Heritage in Kosovo - Progress Report (Pristina: ICO, 2011 ), 3.

${ }^{41}$ The Reconstruction Implementation Commission is an EU-funded project managed by the European Commission Liaison Office and implemented by the Council of Europe. Details of their work in Kosovo can be found at:

http://www.coe.int/t/DG4/CULTUREHERITAGE/COOPERATION/RIC/inc/eng/home.html.

${ }^{42}$ Protective Zones are established at forty-five sites including: Visoki Dečani Monastery, Pec Patriarchate, Gračanica Monastery, Church of Presentation of the Virgin, Lipjan, Devic Monastery, Gorioc Monastery, Budisavci Monastery, Sokolica Monastery, Draganac Monastery, Holy Archangels Monastery, Banjska Monastery, Zočište Monastery, Village of Velika Hoča, Duboki Potok Monastery, Church of Saint George, Gornje Selo, Socanica Monastery, Hermitage with Church, Uljarice, Gazimestan memorial monument, Zvečan medieval fortress, Medieval town of Novo Brdo, Vojnovic Medieval bridge, Vushtrri/Vučitrn, Hermitage of Saint Peter of Koriša. NATO also provided additional physical security for selected sites until the conditions were met for a transfer of their protection to the Kosovo Police force in February 2009. For more information, see: International Civilian Office, Implementation of Special Protective Zones, 11, accessed 22 september 2012, http://www.icokos.org/?id=16 and OSCE, Mission in Kosovo, Department of Human Rights and Communities, accessed 22 September 2012, http://www.osce.org/kosovo/40779.

${ }^{43}$ Martti Ahtisaari, Comprehensive Proposal for the Kosovo Status Settlement, Article 4.1 as quoted in: International Civilian Office, Implementation of Special Protective Zones, 8, accessed 29 April, 2013 http://www.ico-kos.org/data/Image/SPZ_Progress_Report_Final_EV.pdf ${ }_{44}$ Cultural Heritage Without Boarders, "Integrated Conservation Assistance Support For Central and Local Institutions,” 2010 Projects (Stockholm: CHWB, 2010), accessed September 20, 2012, www.chwbkosovo.org.

${ }^{45}$ Wahhabism, the Islamic sect of the Saudis, stresses austerity and prohibits the use of ornament and representational imagery. This is in sharp contrast to "traditional" Balkan mosque architecture, in which imagery and ornament, moulding and elaborate interior frescoes are widely used. See: Stephen Schwartz, "Kosovo Continues Fight Against Wahhabi Infiltration,” The Weekly Standard, March 192012, http://www.weeklystandard.com/blogs/kosovo-continues-fight-against-wahhabi-infiltration_634049.htm.

${ }^{46}$ Stephen Schwartz, "Kosovo Continues Fight Against Wahhabi Infiltration," The Weekly Standard, March 19, 2012, http://www.weeklystandard.com/blogs/kosovo-continues-fight-against-wahhabi-infiltration_634049.htm.

${ }^{47}$ Bevan, The Destruction of Memory, 176, 190. See also: International Crisis Group, "Religion in Kosovo," ICG Balkans Report 105 (2001): 5 , 6.

${ }^{48}$ Sabri Bajgora, quoted in Ted Siefer, Kosovo: Heritage or Sacrilege, http://www.tol.org/client/article/10172-kosovo-heritage-or-sacrilege.html.

${ }^{49}$ Andras Riedlmayer, quoted in Ted Siefer, Kosovo: Heritage or Sacrilege, http://www.tol.org/client/article/10172-kosovo-heritage-orsacrilege.html.

${ }^{50}$ The underlying assumption of the project is that: "The integration of cultural heritage into urban and spatial planning promotes diversity and upholds the right of citizens to partake in culture. When cultural heritage is successfully integrated into municipal plans, it creates conditions for potential growth in the tourism sector." Examples are to be found in Isniq, Drenoc villages and in Deçan and are discussed in: Cultural Heritage Without Boarders, Integrated Conservation: Challenges, Opportunities and Integration, Experiences of Cultural and Natural Heritage into Spatial and Urban Planning in Kosovo, (Pristina: CHWB Kosovo Office, 2011), accessed April 18, 2013, http://www.chwb.org/kosovo/.

${ }^{51}$ Cultural Heritage Without Boarders, Cultural Heritage, Reconciliation, 2005.

${ }^{52}$ Cultural Heritage Without Boarders, Cultural Heritage, Reconciliation, 2005.

${ }^{53}$ Cultural Heritage Without Boarders, 2010 Projects.

${ }^{54}$ Cultural Heritage Without Boarders, "Lessons from Kosovo - How Post-Conflict Society is Dealing with Planning and Cultural Heritage," Naples, September 21, 2012, accessed April 18, 2013,

http://chwbkosovo.org/full.php?id=1348246782\&archive=\&subaction=showfull\&template=full

${ }^{5}$ Cultural Heritage Without Boarders, 2010 Projects. See also: UN Habitat, Visioning as Participatory Planning Tool Learning from Kosovo Practices, (Un Habitat: Nairobi, s.d.), accessed August 16, 2013, http://www.unhabitat-kosovo.org/repository/docs/UN-HABITAT-Visioningweb3.pdf. On p. 86: "The vision statement was backed by an expressive memory map, which was shortly afterwards published as a poster. The public presentation in one of the kullas - restored by Cultural Heritage without Borders and now used as a unique Bed \& Breakfast - was also an expression of a great belief in a better future for a village that had suffered heavily during the 1998-1999 conflict. The visioning workshop provided valuable inputs for the municipal and urban spatial plans." 


\footnotetext{
${ }^{56}$ For more information on Intersos in Kosovo: http://intersos.org/en/countries/europe/kosovo/kosovo.

${ }^{57}$ Bevan, The Destruction of Memory, 176, 190. See also: International Crisis Group, "Religion in Kosovo," ICG Balkans Report 105 (2001): 5 , 6.

${ }^{58}$ For the evaluation of the project see: Sarah Wolferstan, "Community Participation in Heritage in Post-Conflict Kosovo. Promoting Democracy, Dialogue and Reconciliation through Cultural Heritage," in Interpreting the Past. The Future of Heritage. Changing Visions, Attitudes and Contexts in the 21st Century. Selected Papers from the Third Annual Ename International Colloquium (Ghent: Flemish Heritage Institute (VIOE), 2007), 286-288.

${ }^{59}$ Currently ninety-nine UN states recognise the independence of Kosovo and it has become a member country of the IMF and the World Bank as the Republic of Kosovo. The UN Security Council remains divided however - the USA, UK, and France have recognised the declaration of independence while China and Russia have not. The European Union has taken no official position on the issue.

${ }^{60}$ Anthony D. Smith, Professor emeritus of Nationalism and Ethnicity at the London School of Economics and considered one of the founders of the interdisciplinary field of nationalism studies, defines a nation as: "a named human population sharing a historic territory, common myths, and historical memories, as a mass public culture, a common economy and common legal rights and duties for all members." Smith, National Identity, 14.

${ }^{60}$ Simon Lambert and Cynthia Rockwell, eds., Protecting Cultural Heritge in Times of Conflict (Rome: ICCROM, 2011), ix.
} 
Antonenko, Oksana. "Indépendance du Kosovo: Pourquoi la Russie s'y oppose-t-elle?." IFRI: Russie.Nei.Visions, 21(2007).

Arendt, Hannah. The Human Condition: A Study of the Central Dilemma Facing Modern Man. Chicago: University of Chicago Press, 1958.

Assembly of Republic of Kosovo. Law No. 04/L-062 On the Village of Hoçë E Madhe / Velika Hoca. Kosovo, 2012.

Assembly of Republic of Kosovo. Law No. 04/L-066 On Historic Centre of Prizren. Kosovo, 2012.

Batt, Judi. Religion, State and Identity in Central and Eastern Europe. London: Frank Cass, 2002.

Bertelmann Stiftung. The Cultural Dimensions of Conflicts from 1945 to 2007, Introduction and Summary. Guetersloh: Bertelmann Stiftung, 2009.

Bevan, Robert. The Destruction of Memory: Architecture at War. London: Reaktion Books, 2006.

Bokova, Irina. "Culture Under Fire," The New York Times, April 6, 2012.

Bout De Marnhac, Xavier. Report of the Secretary-General on the United Nations Interim Administration Mission in Kosovo, S/2012/603. Washington: UN, 2012.

Cady, Jean-Christian. "Etablir l'état de droit au Kosovo, Succès et échecs des Nations Unies." IFRI Focus Stratégique, 34 (2011).

Coppi Agostinelli, Margarita Alexandra. "Cultural Diplomacy and the Concept of the Other." Paper presented at The International Conference on Cultural Diplomacy and the UN, New York and Washington, February 21-24, 2012.

Council of Europe. "Compendium: Cultural Rights and Ethics." http://www.culturalpolicies.net/web/ethics-human-rights.php

Council of Europe. "Cultural heritage, Spatial Planning and Landscape." http://www.coe.int/t/dg4/cultureheritage/heritage/default_EN.asp?expandable=2

Council of Europe. "Framework Convention on the Value of Cultural Heritage for Society." Online version: http://conventions.coe.int/Treaty/EN/Treaties/Html/199.htm.

Council of Europe. Advisory Committee on the Framework Convention For the Protection of National Minorities, Opinion on Serbia and Montenegro, ACFC/INF/OP/I(2004)002. Brussels: CoE, 2003.

Council of Europe. Advisory Committee on the Framework Convention For the Protection of National Minorities. Brussels: CoE, 2004.

Council of Europe. Advisory Committee on the Framework Convention for the Protection of National Minorities, Opinion on the Implementation of the Framework Convention for the Protection of National Minorities in Kosovo, ACFC/OP/I(2005)004 . Brussels: CoE, 2006.

Council of Europe. Advisory Committee on the Framework Convention for the Protection of National Minorities, Comments of the Government of Serbia on the Second Opinion of the Advisory Committee on the Implementation of the Framework Convention for the Protection of National Minorities by Serbia, GVT/COM/II (2009)002, Brussels: CoE, 2009.

Council of Europe. Advisory Committee on the Framework Convention for the Protection of National

Minorities, Comments by UNMIK to the Second Opinion on the Implementation of the Framework Convention for the Protection of National Minorities in Kosovo,

GVT/COM/II(2010)002. Brussels: CoE, 2010.

Council of Europe. Charter on the Functioning of the European Heritage Network, CDPATEP (2011) 25.

Brussels: CoE, 2011.

Council of Europe. Council of Europe's White Paper on Intercultural Dialogue. Brussels: CoE, 2008.

Council of Europe. European Manifesto for Multiple-Cultural Affiliation. Brussels: CoE, s.d.

Council of Europe. Forward Planning: The Function of Cultural Heritage in a Changing Europe, Expert's Contributions. Brussels: CoE, s.d.

Council of Europe. Resolution ResCMN(2006)9 on the Implementation of the Framework Convention for the Protection of National Minorities in Kosovo (Republic of Serbia)1. Brussels: CoE, 2006. 
Council of Europe. Steering Committee for Cultural Heritage, Heritage from Elsewhere, Heritage of

Others, Outline of an Awareness-Raising Project. Brussels: CoE, 2004.

Cultural Heritage Withour Boarders. 2010 Projects. Stockholm: CHwB, 2010.

Cultural Heritage Without Boarders. Conservation and Development Plan for the Historic Zone of Prizren Kosovo. Stockholm: CHwB, 2011.

Cultural Heritage Without Boarders. Cultural Heritage, Reconciliation, Reconstruction, Hopes for the Future. Stockholm: CHwB, 2005.

Cultural Heritage Without Boarders. Heritage of Pristina, Report Series 12/2008. Stockholm: CHwB, 2008.

Cultural Heritage Without Boarders. The Western Balkan Regional Museum Network, Stockholm: CHwB, 2011.

de Vattel, Eugène. Le droit des gens ou Principes de la loi naturelle appliqués à la conduite et aux affaires des nations et des souverains. Neuchâtel, 1758.

Dimitrijevic, Dejan. Mémoire et histoire dans la culture politique Serbe. Paris: IFRI, 1999.

European Federation of Psychologists' Associations. Lessons Learned in Psychosocial Care after Disaster. Brussels: EFPA, 2010.

European Security Forum. "What is 'Just' Secession? (Is Kosovo Unique?)." ESF working paper 28 (2008).

Federal Republic of Yugoslavia. Report Submitted by the FRY Pursuant to Article 25, Paragraph 1 of the Framework Convention for the Protection of National Minorities, ACFC/SR(2002)003. Brussels: CoE, 2002.

Gossiaux, Jean-François. "Les Deux Passés du Kosovo." Socio-Antropologie, 4 (1998).

Gricourt, Sebastien. "Kosovo deux ans après l'indépendance." Note de l'IFRI (2010). Kumbaro, Dajena. The Kosovo Crisis in an International Law Perspective: Self-Determination, Territorial Integrity and the NATO Intervention, Final Report. Brussels: NATO, 2001.

Hawkesworth, Celia. Religious Quest and National Identity in the Balkans. New York: Palgrave, 2001.

Herscher, Andrew, and Riedlmayer Andras. "Monument and Crime: The Destruction of Historic Architecture in Kosovo." Grey Room, 1 (2000).

Hupchick, Dennis P., and Harold E. Cox. The Palgrave Concise Historical Atlas of The Balkans. New York: Palgrave, 2001.

Institute for Cultural Diplomacy. Evolution of Cultural Diplomacy. Berlin: ICD, s.d.

Institute for Cultural Diplomacy. Executive Summary of the ICD Cultural Diplomacy Outlook 2011. Berlin: ICD, 2011.

International Court of Justice. Accordance with International Law of the Unilateral Declaration of Independence in Respect of Kosovo, No 2010/25, ICJ. The Hague: ICJ, 2010.

International Crisis Group. "Breaking the Kosovo Stalemate: Europe's Responsibility." ICG Europe Report 185 (2007).

International Crisis Group. "Kosovo and Serbia After the ICJ Opinion." ICG Europe Report 206 (2010).

International Crisis Group. "Kosovo and Serbia: A Little Goodwill Could Go A Long Way." ICG Europe Report 215 (2012).

International Crisis Group. “Kosovo Countdown: A Blueprint for Transition.” ICG Europe Report 188 (2007).

International Crisis Group. “Kosovo: Strpce, a Model Serb Enclave?” ICG Policy Briefing, Europe Briefing 56 (2009).

International Crisis Group. “Kosovo's First Month.” ICG Policy Briefing, Europe Briefing 47(2008). International Crisis Group. “Kosovo's Fragile Transition.” ICG Europe Report 196 (2008).

International Crisis Group. "North Kosovo: Dual Sovereignty in Practice." ICG Europe Report, 211 (2011).

International Crisis Group. "Religion in Kosovo.” ICG Balkans Report 105 (2001). 
International Crisis Group. "Serb Integration in Kosovo: Taking the Plunge.” ICG Europe Report 200 (2009).

International Crisis Group. "The Rule of Law in Independent Kosovo.” ICG Europe Report 204 (2010).

International Monetary Fund. IMF Surveys: Kosovo, IMF, 2012. http://www.imf.org/external/pubs/ft/survey/so/2012/car071712b.htm.

Kaplan, Flora. Museums and the Making of Ourselves: The Role of Objects in National Identity. London: Leicester University Press, 1968.

Kostadinova, Tonka. "Cultural Diplomacy in War-affected Societies: International and Local Policies in the Post-Conflict (re-) Construction of Religious Heritage in Former Yugoslavia." Paper presented at the Academy for Cultural Diplomacy, Berlin, June 10-17, 2011.

Lab for Culture. Accessed August 20, 2012. http://www.labforculture.org/en/projects/collections/10-casestudies/videoletters

Lambert, Simon, and Cynthia Rockwell, eds. Protecting Cultural Heritage in Times of Conflict. Rome: ICCROM, 2011.

Laxman, Yadav. Culture of European Identity. Brussels: Ceris MA Dissertation under supervision of Dr. Willy Stevens, 2012.

Lehe, Stefan. Kosovo and Serbia: Toward a Normal Relationship, Brussels: Carnegie Policy Outlook, 2013.

Matsuura, Koïchiro. Cultural Heritage in South-East Europe: Kosovo. Protection and Conservation of a Multi-Ethnic Heritage in Danger. Mission Report. Paris: UNESCO, 2004.

Moreau Defarges, Philippe, ed. Europe, Russie: Belgique - Kosovo: La Félure. Paris: IFRI, 2009.

Nikolic, Tomislav. Statement for the General Assembly of the United Nations, 67th session. New York: UN, 2012.

Office of the High Commissioner for Human Rights. General Comment No12: The Right to Self Determination of People (Art.1) 13/04/1984, CCPR General Comment No12. Washington: UN, 1984.

Palmer, Robert. Reconstruction Implementation Commission for Serbian Orthodox Religious Sites in Kosovo. Brussels: CoE, 2010.

Pelko, Stojan. Implementation and Monitoring Council Established. Kosovo: European Union Office in Kosovo, 2013.

Perrot, Odile. "Kosovo une indépendance supervisée." Analyse de CFA 1 IFRI, (2011).

Serbia. Second Report Submitted by Serbia Pursuant to Article 25, Paragraph 2 of the International Framework Convention for the Protection of National Minorities, Brussels: CoE, 2008.

Siefer, Ted. "Kosovo: Heritage or Sacrilege." In Transitions Online: Regional Intelligence. Accessed July 23, 2003. http://www.tol.org/client/article/10172-kosovo-heritage-or-sacrilege.html.

Smith, Anthony D. National Identity, New York: Penguin Books, 1991.

Therond, Daniël. Heritage and Beyond: Prospects Opened Up by the Faro Convention. Brussels: CoE, 2009.

Tolhuis, H. (registrar). Case IT-02-54-T, Prosecution's Submission of the Expert Report of Andras Riedlmayer. The Hague: The International Criminal Court for the Former Yugoslavia, 2002.

UNESCO. Cultural Heritage in South-East Europe: Kosovo, 2004. http://erc.unesco.org/seeconference.

UNESCO. High Panel on Peace and Dialogue Among Cultures. Paris: UNESCO, 2010.

UNESCO. UNESCO Constitution: Convention for the Protection of Cultural Property in the Event of Armed Conflict with Regulations for the Execution of the Convention 1954. Paris: UNESCO, 1954.

UNESCO. UNESCO Constitution: Second Protocol to the Hague Convention of 1954 for the Protection of Cultural Property in the Event of Armed Conflict 1999. Paris: UNESCO, 1999.

UNESCO. UNESCO Declaration Concerning the Intentional Destruction of Cultural Heritage. Paris: UNESCO, 2003. 
United Nations Security Council. Letter dated 26 March 2007 from the Secretary-General addressed to the President of the Security Council, Addendum Comprehensive Proposal for the Kosovo Status Settlement, Washington: UN, 2007.

UNMIK. Observations on the Opinion of the Advisory Committee on the Framework Convention for the Protection of National Minorities (Adopted 25 November 2005), Washington: UN, 2006.

UNMIK. Progress Report on the Implementation of the Framework Convention for the Protection of National Minorities in Kosovo, ACFC(2008)001. Brussels: CoE, 2008.

UNMIK. Report Submitted ...Pursuant to Article 2.2 of the Agreement between UNMIK and the Council of Europe Related to the Framework Convention for the Protection of National Minorities, ACFC(2005)003. Brussels: CoE, 2005.

Vale, Lawrence. Architecture, Power and National Identity, New Haven: Yale University Press, 1992.

Wolferstan, Sarah. "Community Participation in Heritage in Post-Conflict Kosovo. Promoting Democracy, Dialogue and Reconciliation through Cultural Heritage." In Interpreting the Past. The Future of Heritage. Changing Visions, Attitudes and Contexts in the 21st Century. Selected Papers from the Third Annual Ename International Colloquium. Ghent, 2007. 